\title{
Morphometric Evaluation of the Greater Palatine Foramen in Adult Sri Lankan Skulls
}

\author{
Evaluación Morfométrica del Foramen Palatino Mayor en Craneos Adultos de Sri Lanka
}

\author{
Isurani Ilayperuma*; Ganananda Nanayakkara* \& Nadeeka Palahepitiya*
}

\begin{abstract}
ILAYPERUMA, I.; NANAYAKKARA, G. \& PALAHEPITIYA, N. Morphometric evaluation of the greater palatine foramen in adult Sri Lankan skulls. Int. J. Morphol., 32(4):1418-1422, 2014.

SUMMARY: Evidence supports a clear racial variation in the position of the greater palatine foramen. Therefore detailed knowledge of the population specific data on biometric features of the greater palatine foramen will facilitate therapeutic, local anesthetic and surgical manipulations in the maxillo-facial region. The goal of this study was to elucidate the morphological features and precise anatomical position of the greater palatine foramen with reference to surrounding anatomical landmarks in an adult Sri Lankan population. A total of one hundred and thirty six adult dry skulls were assessed to determine the number, shape, direction of opening of the greater palatine foramen and straight distance from it to the palatine midline, posterior margin of the hard palate and incisive fossa. The position of the greater palatine foramen was determined in relation to the maxillary molars. The results indicated that $82.35 \%$ of the greater palatine foramina had an oval outline and located in line with the long axis of the upper third molar (77.20\%). The greater palatine foramen was located $15.24 \mathrm{~mm}$ lateral to the median sagittal plane of the hard palate and $4.51 \mathrm{~mm}$ anterior to the posterior border of the hard palate. In $50 \%$ of the cases the greater palatine foramen opened in an antero-medial direction. The results of the current study further highlight the racial differences in the position of the greater palatine foramen and emphasize the need for meticulous preoperative evaluation of the greater palatine foramen in patients who are candidates for maxillo-facial surgeries and regional block anesthesia.
\end{abstract}

KEY WORDS: Greater palatine foramen; Morphometry; Sri Lanka.

\section{INTRODUCTION}

The hard palate is formed by the union of palatine processes of the maxilla anteriorly and the horizontal plates of the palatine bone posteriorly. The vault of the hard palate is traversed by a crucial suture formed by the junction of the four bones of which it is composed. The foramen located postero-laterally, on either side of the bony palate marks the greater palatine foramen. It represents the lower end of the greater palatine canal which transmits the greater palatine vessels and nerve from the pterygopalatine fossa. Lesser palatine foramina are located in the pyramidal process of palatine bone behind the greater palatine foramina and harbor the lesser palatine nerve and vessels (Sinnathamby, 1999; Williams et al., 2000).

Numerous methods have been employed to produce profound regional anesthesia of the maxillary arch (Mercuri, 1979; Baddour et al., 1979; Malamed \& Trieger, 1983). The most commonly described route of administration is inserting a needle into the greater palatine canal through the greater palatine foramen and depositing the local anesthetic solution into the superior aspect of the pterygopalatine fossa, where the trunk of the maxillary nerve lies (Baddour et al.; Malamed \& Trieger). Maxillary nerve block in the greater palatine canal is used to accomplish regional anesthesia of an entire quadrant of maxillary teeth, adjacent bone and soft tissue to allow exodontia, palatal surgery, quadrant restorative dentistry, Caldwell-Luc procedure or periodontal therapy (Wong \& Sved, 1991; Lepere, 1993). It is also useful when the extent of buccal odontogenic infection contraindicates infiltration anesthesia (Methathrathip et al., 2005). Additionally, this technique is used effectively in sinus and endodontic procedures, trauma of the maxilla, diagnosis and treatment of chronic oral and maxillofacial pain syndromes and when general anesthesia is not available or contraindicated for a definitive surgical intervention (Isen \& Hawkins, 1995; Malamed, 1998). Furthermore, it is indicated for hemostasis and anesthesia in endoscopic sinus surgery, septorhinoplasty,

\footnotetext{
*Department of Anatomy, Faculty of Medicine, University of Ruhuna, Galle, Sri Lanka.
} 
and posterior epistaxis (Douglas \& Wormald, 2006). It has been shown that recovery from general anaesthesia is better when regional block is used for intra and post-operative analgesia (Bösenberg \& Kimble, 1995).

A large body of evidence shows a clear racial variation in the morphometry and relative position of the greater palatine foramen in relation to the maxillary molars among different populations (Wang et al., 1988; Ajmani, 1994; Jaffar \& Hamadah, 2003; Methathrathip et al.; Saralaya \& Nayak, 2007; Chrcanovic \& Custódio, 2010). It is also interesting to note that traits such as localization of the facial foramina not only differ between populations of different geographic zones but also within the inhabitants of the same geographic environment (Saralaya \& Nayak; Ilayperuma et al., 2009).

Despite its significance little is known concerning the morphological details and the location of the greater palatine foramen in Sri Lankans, inhabitants of the South Asian country. Hence, this study was carried out to elucidate the shape, orientation and position of the greater palatine foramen in relation to the surgically encountered anatomical landmarks and maxillary molars in an adult Sri Lankan population.

\section{MATERIAL AND METHOD}

A total of 136 adult dry skulls with complete dentition, homogenous in arch form and intact alveolar bridges collected from the Department of Anatomy, Faculty of Medicine, University of Ruhuna, Sri Lanka, were used for this study. The age group of the cadavers varied between 48-67 years.

Both sides of the hard palate were assessed and the number of greater palatine foramina present and their shape was recorded by direct visual inspection. The shape of the greater palatine foramen was described as displaying an oval or a circular outline. The presences of lesser palatine foramina were also recorded.

The direction of the opening of greater palatine canal was determined by inserting a needle into the greater palatine foramen. The orientation of the greater palatine canal was described as antero-medial, anterior or antero-lateral. The shape of the palatal vault was recorded as arched or flat (Methathrathip et al.).

The location of the greater palatine foramen was evaluated by the straight transverse distance from the center of the greater palatine foramen to the mid sagittal plane of the hard palate, straight vertical distance from the center of the greater palatine foramen to the posterior margin of the hard palate and straight distance from the center of the greater palatine foramen to the incisive fossa. All the measurements were recorded using a digital sliding caliper (Mitutoyo, Japan) capable of measuring to the nearest $0.01 \mathrm{~mm}$.

The locational relationship of the greater palatine foramen in relation to the upper molars was recorded as either in line with the longitudinal axis of the maxillary second molar or third molar or as lying between the adjacent maxillary second and third molars or behind the maxillary third molar (Ajmani).

All the measurements were repeated thrice and the mean was taken for further analysis. Furthermore, the measurements were recorded by the same person to minimize the inter-observer errors in methodology. Results were expressed as mean $\pm \mathrm{SD}$ and analyzed using the Statistical Package for Social Sciences (SPSS), 15th version. A comparison of the mean values between the sides was performed using the t-test. $\mathrm{P}$ value $<0.05$ was considered statistically significant.

\section{RESULTS}

All the skulls studied displayed a single greater palatine foramen on both sides. Multiple lesser palatine foramina were found in $1.47 \%$ of the skulls. Of the skulls that showed multiple foramina, all had ipsilateral double foramina. The greater palatine foramen was oval in $82.35 \%$ and circular in outline in $17.65 \%$ of the subjects. Most of the palatal vaults were arched (86.76\%) while only $13.24 \%$ were flat.

The linear measurements of the greater palatine foramen with respect to the surrounding anatomical landmarks are summarized in Table I. These measurements did not vary significantly $(\mathrm{P}>0.05)$ between the sides demonstrating a remarkable bilateral symmetry.

Frequencies of the position of the greater palatine foramen in relation to the upper molars are shown in Table II and illustrated in Figure 1. The most common position for the greater palatine foramen relative to the maxillary molars was found to be in line with the third maxillary molar (77.2\%), followed by a position between second and third maxillary molars $(21.68 \%)$. Together, these two positions made an overall prevalence of $98.89 \%$. No greater palatine foramina were located behind the third molar on the right side and only $0.74 \%$ on the left side. 
Table I. Morphometric measurements of the greater palatine foramen between sides.

\begin{tabular}{|c|c|c|}
\hline Measurements & $\begin{array}{l}\text { Right side } \\
(\text { Mean } \pm \text { SD }) \mathrm{mm}\end{array}$ & $\begin{array}{l}\text { Left side } \\
(\text { Mean } \pm \text { SD }) \mathrm{mm}\end{array}$ \\
\hline GPF to maxillary midline & $15.20 \pm 1.24$ & $15.28 \pm 1.06$ \\
\hline GPF to incisive fossa & $41.20 \pm 1.10$ & $15.28 \pm 1.06$ \\
\hline GPF to PBHP & $4.52 \pm 1.86$ & $4.50 \pm 1.03$ \\
\hline
\end{tabular}

Table II. Location of greater palatine foramen in relation to upper molars.

\begin{tabular}{lcc}
\hline Location & Right side & Left side \\
\hline In line with second molar & $0.74 \%$ & $0.74 \%$ \\
Between second and third molar & $21.32 \%$ & $22.05 \%$ \\
In line with third molar & $77.94 \%$ & $76.47 \%$ \\
Behind third molar & $0.00 \%$ & $0.74 \%$ \\
\hline
\end{tabular}

$*=\mathrm{P}<0.05$

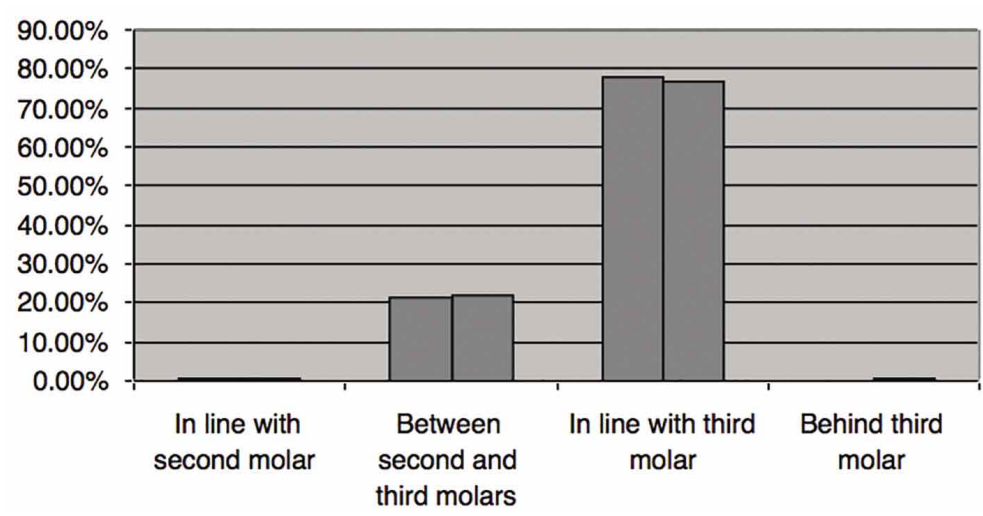

Fig. 1. Location of greater palatine foramen in relation to upper molars.

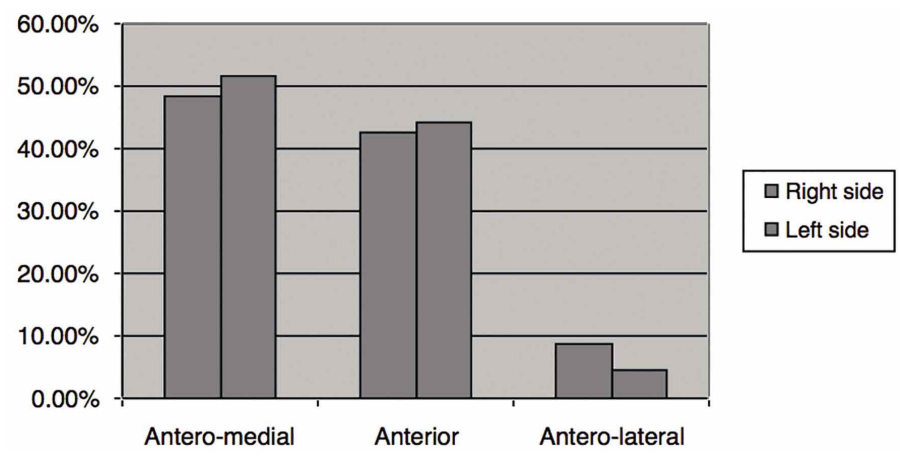

Fig. 2. Direction of opening of greater palatine foramen between sides.

\section{DISCUSSION}

The present study provides valuable new data pertaining to the greater palatine foramen in relation to the surrounding anatomical landmarks in an adult Sri Lankan population. Population specific
Frequencies of the orientation of the greater palatine foramen are summarized in Table III and illustrated in Figure 2. Majority (50\%) of the greater palatine canals were directed antero-medially on the lateral margin of the hard palate. Only in $43.38 \%$ of the cases it was directed anteriorly and in $6.62 \%$ antero-laterally.

Table III. Direction of opening of greater palatine foramen between sides.

\begin{tabular}{lcc}
\hline Orientation & Right side & Left side \\
\hline Antero-medial & $48.53 \%$ & $51.47 \%$ \\
Anterior & $42.65 \%$ & $44.12 \%$ \\
Antero-lateral & $8.82 \%$ & $4.41 \%$ \\
\hline
\end{tabular}

\begin{tabular}{|l|}
\hline$\square$ Right side \\
$\square$ Left side \\
\hline
\end{tabular}

linear measurements concerning the location of greater palatine foramen will facilitate precise identification of the greater palatine foramen in therapeutic, diagnostic, local anesthetic and surgical procedures of the maxillo-facial region (Mercuri; Douglas \& Wormald).

Evidence shows a clear racial variation in the relative position of the greater palatine foramen with respect to the surrounding anatomical landmarks among different populations. The mean distances from greater palatine foramen to the mid sagittal plane of the hard palate observed in this study (right side: $15.20 \pm 1.24 \mathrm{~mm}$; left side: $15.28 \pm 1.06 \mathrm{~mm}$ ) was lower than those reported in Chinese (Wang et al.); Nigerians (Ajmani), Iraqis (Jaffar \& Hamadah) and Thais (Methathrathip et $a l$.) whereas it was higher than those reported for South Indians (Saralaya \& Nayak) and Brazilians (Chrcanovic \& Custódio). Furthermore, the mean distances from greater palatine foramen to the posterior margin of hard palate observed in this study (right side: $4.52 \pm 1.86 \mathrm{~mm}$; left side: $4.50 \pm 1.03$ 
$\mathrm{mm}$ ) was lower than those reported in Iraqis (Jaffar \& Hamadah) whereas it was higher than those reported for Nigerians (Ajmani); Thais (Methathrathip et al.); South Indians (Saralaya \& Nayak) and Brazilians (Chrcanovic \& Custódio). It is speculated that variability in location of the greater palatine foramen may be due to sutural growth occurring between maxilla and palatine bones (Chrcanovic \& Custódio). It has also been stated that antero-posterior dimensions of the palate increases with the eruption of posterior teeth (Slavkin et al., 1966). Further these differences might also be attributed to the ethnic factor (Ongeti et al., 2008). Population specific linear measurements have a clinical implication as it will enable clinicians to locate the greater palatine foramen in a consistently reliable manner thus avoiding injury to the neurovascular bundle that exit through it (Mercuri; Malamed \& Trieger; Chrcanovic \& Custódio).

The modal position of the greater palatine foramen in Sri Lankans was in line with the long axis of the third upper molar (55.56\%). This is in agreement with the results of previous studies on Negroids (Langenegger et al., 1983), Kenyans (Hassanali \& Mwaniki, 1984); Nigerians (Ajmani, 1994); Thais (Methathrathip et al., 2005); South Indians (Saralaya \& Nayak, 2007) and Brazilians (Chrcanovic \& Custódio, 2010) but different from Chinese where it was found predominantly between the second and third molars (Wang et al., 1988). The second most common position of the greater palatine foramen in Negroid (Langenegger et al., 1983) and Brazillians (Chrcanovic \& Custódio, 2010) was distal to the third maxillary molar whereas in Kenyans (Hassanali \& Mwaniki, 1984); Nigerians (Ajmani); Thais (Methathrathip et al.); South Indians (Saralaya \& Nayak) and Sri Lankans it was a position between second and third maxillary molars. The results of the current study further highlight the racial differences in the modal position of the greater palatine foramen in relation to the upper molars observed among different populations. Such diversity in the location of greater palatine foramen may be attributed to ethnic factors (Cutright et al., 2003).

The opening of the greater palatine foramen was directed antero-medially in majority (50\%) of Sri Lankan skulls. This was in agreement with Kenyan (Hassanali \& Mwaniki); Iraqis (Jaffar \& Hamadah) and South Indians (Saralaya \& Nayak) whereas it was different from the observations of Chinese (Wang et al.) and Brazilians (Chrcanovic \& Custódio) where the foramen was predominantly directed anteriorly. Our results reinforce the racial variability in the orientation of the greater palatine foramen. From a clinical point of view, it may explain the occasional difficulty encountered when attempting to insert a needle into the greater palatine foramen (Ajmani).
The standard Anatomy and Surgery texts describe the location of greater palatine foramen near the lateral palatal margin (Williams et al.), between the palatine bone and maxilla in line with the last molar tooth (Sinnathamby), in the postero-lateral margin (Gardner et al., 1975), medial to last molar (Moore, 1980), opposite the last molar (Romanes, 1981), opposite the second molar (Seldan, 1948), opposite the third molar or anywhere between the second and third molars (Shane, 1975). In view of these inconsistent and vague descriptions, the significance of analyzing the population specific data pertaining to the location of greater palatine foramen cannot be overestimated.

Information concerning the skull foraminal size and symmetry is increasingly important with the advancement of endoscopic procedures and radiological techniques such as magnetic resonance imaging (MRI) and computed tomography (CT) that makes difficult diagnoses of pathologic conditions of skull foramina possible (Cutright et al.).

The maxillary nerve block in the greater palatine canal via greater palatine foramen has been stated as the as the most predictable, reliable and safest means of obtaining profound maxillary anesthesia provided that there is strict adherence to the anatomical landmarks (Malamed \& Trieger). The success of the technique is centered on the precise identification of the greater palatine foramen (Lepere; Methathrathip et al.). Thus a detailed knowledge of the precise anatomical location of the greater palatine foramen using unequivocal and well defined anatomical landmarks that can be easily located in living subjects will be imperative in modern surgical procedures and anesthetic nerve blocks, which in turn will invariably reduce the potential complications encountered during clinical procedures (Malamed \& Trieger; Methathrathip et al.).

ILAYPERUMA, I.; NANAYAKKARA, G. \& PALAHEPITIYA, N. Evaluación morfométrica del foramen palatino mayor en craneos adultos de Sri Lanka. Int. J. Morphol., 32(4):1418-1422, 2014.

RESUMEN: La evidencia apoya una variación racial evidente en la posición del foramen palatino mayor. Así, el conocimiento de datos específicos de la población sobre las características biométricas de las aperturas palatinas facilitará la realización de tratamientos terapéuticos, anestésicos locales y manipulaciones quirúrgicas en la región maxilofacial. El objetivo de este estudio fue determinar las características morfológicas y la posición anatómica precisa del foramen palatino mayor con referencia a estructuras anatómicas circundantes en una población adulta de Sri Lanka. Un total de 136 cráneos secos, adultos, fueron evaluados para determinar el número, la forma, la dirección de apertura del foramen palatino mayor y la distancia recta a la línea mediana palatina, al margen posterior del paladar duro y la fosa incisiva. La posición del foramen palatino mayor se determinó en relación con los molares superiores. Los resultados indicaron que $82,35 \%$ de los forámenes palatinos mayores 
tenían un contorno ovalado y situado en línea con el eje largo del tercer molar superior $(77,20 \%)$. El foramen palatino mayor se encontró $15,24 \mathrm{~mm}$ lateral del plano sagital del paladar duro y 4,51 $\mathrm{mm}$ por delante del margen posterior del paladar duro. En el $50 \%$ de los casos la apertura de los forámenes fue en dirección antero-medial. Los resultados señalan las diferencias raciales en la posición del foramen palatino mayor y apuntan a la necesidad de una evaluación preoperatoria minuciosa en los pacientes candidatos a cirugías maxilofaciales y anestesia de bloque regional.

PALABRAS CLAVE: Foramen palatino mayor; Morfometría; Sri Lanka.

\section{REFERENCES}

Ajmani, M. L. Anatomical variation in position of the greater palatine foramen in the adult human skull. J. Anat., 184(Pt. 3):635-7, 1994.

Bösenberg, A. T. \& Kimble, F. W. Infraorbital nerve block in neonates for cleft lip repair: anatomical study and clinical application. $\mathrm{Br} . J$. Anaesth., 74(5):506-8, 1995.

Baddour, H. M.; Hubbard, A. M. \& Tilson, H. B. Maxillary nerve block used prior to awake nasal intubation. Anesth. Prog., 26(2):43-5, 1979.

Chrcanovic, B. R. \& Custódio, A. L. Anatomical variation in the position of the greater palatine foramen. J. Oral Sci., 52(1):109-13, 2010.

Cutright, B.; Quillopa, N. \& Schubert, W. An anthropometric analysis of the key foramina for maxillofacial surgery. J. Oral Maxillofac. Surg., 61(3):354-7, 2003.

Douglas, R. \& Wormald, P. J. Pterygopalatine fossa infiltration through the greater palatine foramen: where to bend the needle. Laryngoscope, 116(7):1255-7, 2006.

Gardner, E.; Gray, D. J. \& O’Rahilly, R. Anatomy: A Regional Study of Human Structure. $4^{\text {th }}$ ed. Philadelphia, W. B. Saunders Company, 1975.

Hassanali, J. \& Mwaniki, D. Palatal analysis and osteology of the hard palate of the Kenyan African skulls. Anat. Rec., 209(2):273-80, 1984.

Ilayperuma, I.; Nanayakkara, G. \& Palahepitiya, N. Morphometric analysis of the mental foramen in adult Sri Lankan mandibles. Int. J. Morphol., 27(4):1019-24, 2009.

Isen, D. A. \& Hawkins, J. M. The pharmacology of local anesthetics. Ont. Dent., 72(6):18-22, 1995.

Jaffar, A. A. \& Hamadah, H. J. An analysis of the position of the greater palatine foramen. J. Basic Med. Sci., 3(1):24-32, 2003.

Langenegger, J. J.; Lownie, J. F. \& Cleaton-Jones, P. E. The relationship of the greater palatine foramen to the molar teeth and pterygoid hamulus in human skulls. J. Dent., 11(3):249-56, 1983.

Lepere, A. J. Maxillary nerve block via the greater palatine canal: new look at an old technique. Anesth. Pain Control Dent., 2(4):195-7, 1993.
Malamed, S. F. \& Trieger, N. Intraoral maxillary nerve block: an anatomical and clinical study. Anesth. Prog., 30(2):44-8, 1983.

Malamed, S. F. Handbook of local anesthesia. $4^{\text {th }}$ ed. St. Louis, Mosby, 1998.

Mercuri, L. G. Intraoral second division nerve block. Oral Surg. Oral Med. Oral Pathol., 47(2):109-13, 1979.

Methathrathip, D.; Apinhasmit, W.; Chompoopong, S.; Lertsirithong, A.; Ariyawatkul, T. \& Sangvichien, S. Anatomy of greater palatine foramen and canal and pterygopalatine fossa in Thais: considerations for maxillary nerve block. Surg. Radiol. Anat., 27(6):511-6, 2005.

Moore, K. L. Clinically Oriented Anatomy. Baltimore, Williams and Wilkins, 1980

Ongeti, K.; Hassanali, J. \& Saidi, H. Biometric features of facial foramina in adult Kenyan skulls. Eur. J. Anat., 12(2):89-95, 2008.

Romanes, G. R. Cunningham's manual of practical Anatomy. $15^{\text {th }}$ ed. Oxford, Oxford University Press, 1986.

Saralaya, V. \& Nayak, S. R. The relative position of the greater palatine foramen in dry Indian skulls. Singapore Med. J., 48(12):1143-6, 2007.

Selden, H. M. Practical anesthesia for dental and oral surgery. $3^{\text {rd }}$ ed. Philadelphia, Lea Febiger, 1948.

Shane, S. M. E. Principles of sedation, local and general anesthesia in dentistry. Illinois, Charles C. Thomas, 1975.

Sinnathamby, C. S. Last's Anatomy Regional and Applied. $10^{\text {th }}$ ed. Edinburgh, Churchill Livingstone, 1999.

Slavkin, H. C.; Canter, M. R. \& Canter, S. R. An anatomic study of the pterygomaxillary region in the craniums of infants and children. Oral Surg. Oral Med. Oral Pathol. 21(2):225-35, 1966.

Wang, T. M.; Kuo, K. J.; Shih, C.; Ho, L. L. \& Liu, J. C. Assessment of the relative locations of the greater palatine foramen in adult Chinese skulls. Acta. Anat. (Basel), 132(3):182-6, 1988.

Williams, P. L.; Bannister, L. H.; Berry, M. M.; Collins, P.; Dyson, M. \& Dussek, J. E. Gray's Anatomy: The anatomical basis of medicine and surgery. $38^{\text {th }}$ ed. New York, Churchill Livingstone, 2000.

Wong, J. D. \& Sved, A. M. Maxillary nerve block anaesthesia via the greater palatine canal: a modified technique and case reports. Aust. Dent. J., 36(1):15-21, 1991.

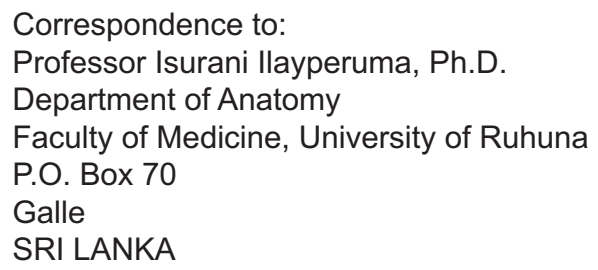

Email: iisurani@yahoo.com

Received: 23-04-2014

Accepted: 21-10-2014 